\title{
Short and long term results after intracoronary stenting in human coronary arteries: monocentre experience with the balloon-expandable Palmaz- Schatz stent
}

\author{
Michael Haude, Raimund Erbel, Uwe Straub, Ulrich Dietz, Jürgen Meyer
}

\begin{abstract}
Objective_-Intracoronary stenting was designed to overcome acute complications after percutaneous transluminal coronary angioplasty and to achieve a reduced rate of restenosis, both of which are major limitations of this well accepted method for treating coronary heart disease. This report describes the experience at one centre with the implantation of balloon-expandable Palmaz-Schatz stents and focuses on device related complications and the short and long term angiographic outcome.
\end{abstract}

Design-A retrospective data analysis.

Patients-Stenting was attempted in 50 patients. Restenosis after an initially successful angioplasty procedure, inadequate postangioplasty results, saphenous coronary bypass stenoses, and bail-out situations were regarded as indications.

Main outcome measures and resultsIn 49 of 50 attempted patients 61 stents (1-4 per patient) were implanted. Delivery problems occurred in three patients and were successfully overcome in two patients. Bail-out situations were successfully managed in 16 patients. Complications included acute thrombus formation within the stent immediately after implantation in one patient, which was successfully treated by thrombolysis. One patient was sent for bypass surgery the day after implantation; another died 10 days after implantation for unknown reasons. Subacute stent thrombosis occurred in seven patients 59 days after implantation and was successfully treated by thrombolysis or balloon angioplasty in five patients. Bleeding complications occurred in nine patients, five of whom required blood transfusions. Angiography showed long term vessel patency after 4-6 months in $31(76 \%)$ of the 41 patients who were followed up, restenosis in six (14\%), and reocclusion in four $(10 \%)$. Late restenosis or reocclusion was found in five $(15 \%)$ of 33 patients with a single stent in contrast to five $(63 \%)$ of eight patients with multiple stents.

Conclusions-Balloon-expandable intracoronary stenting is a feasible method for treating the acute complications of balloon angioplasty. It reduced the rate of restenosis for single stent implantation. Subacute thrombotic events must be regarded as previously unknown and serious complications.

Although percutaneous transluminal coronary angioplasty (PTCA) is widely accepted as the best intervention for the treatment of coronary heart disease in patients presenting with stable and unstable angina, serious limitations continue despite the progress that has been made. In particular, the incidence of acute complications after balloon angioplasty-such as dissections, vessel rupture, and acute thrombosis with or without consequent myocardial infarction-has been reduced but they remain unpredictable factors. ${ }^{1-15}$ Furthermore, long term success is limited by the rate of late restenosis, which ranges from $14 \%$ to $44 \%$ depending on patients population and, primarily, on the definition of restenosis. ${ }^{1-}$ 310 15-18 Intracoronary stenting was designed to overcome the acute complications of balloon angioplasty and reduce the number of requests for surgical interventions, ${ }^{19-22}$ and also to reduce the late restenosis rate. ${ }^{22-29} \mathrm{Dif}$ ferent stent types have been developed and implanted into human coronary arteries after previous animal studies had produced promising results. ${ }^{19-2225-37}$

We report experience at one centre of the implantation of balloon-expandable PalmazSchatz stents in human coronary arteries.

\section{Patients and methods}

PALMAZ-SCHATZ STENT

This balloon-expandable stent consists of two stainless steel meshes connected via a single bridge to improve flexibility (fig 1). Balloon inflation expands the stent up to the maximum balloon diameter pressing it against the vessel wall. Only low inflation pressures are necessary to achieve complete stent expansion, which reduces the risk of balloon rupture. ${ }^{3536}$ The expanded stent remains in position after balloon deflation.

\section{PATIENTS}

Intracoronary stenting was attempted in 50 patients (table 1) (two women and 48 men, aged 41-76) presenting with at least one of the 
Figure 1 Balloonexpandable PalmazSchatz stainless steel stent before balloon inflation (upper panel), after balloon inflation (middle panel), by the expanded balloon (small black arrows), and after balloon deflation and withdrawal (lower panel).

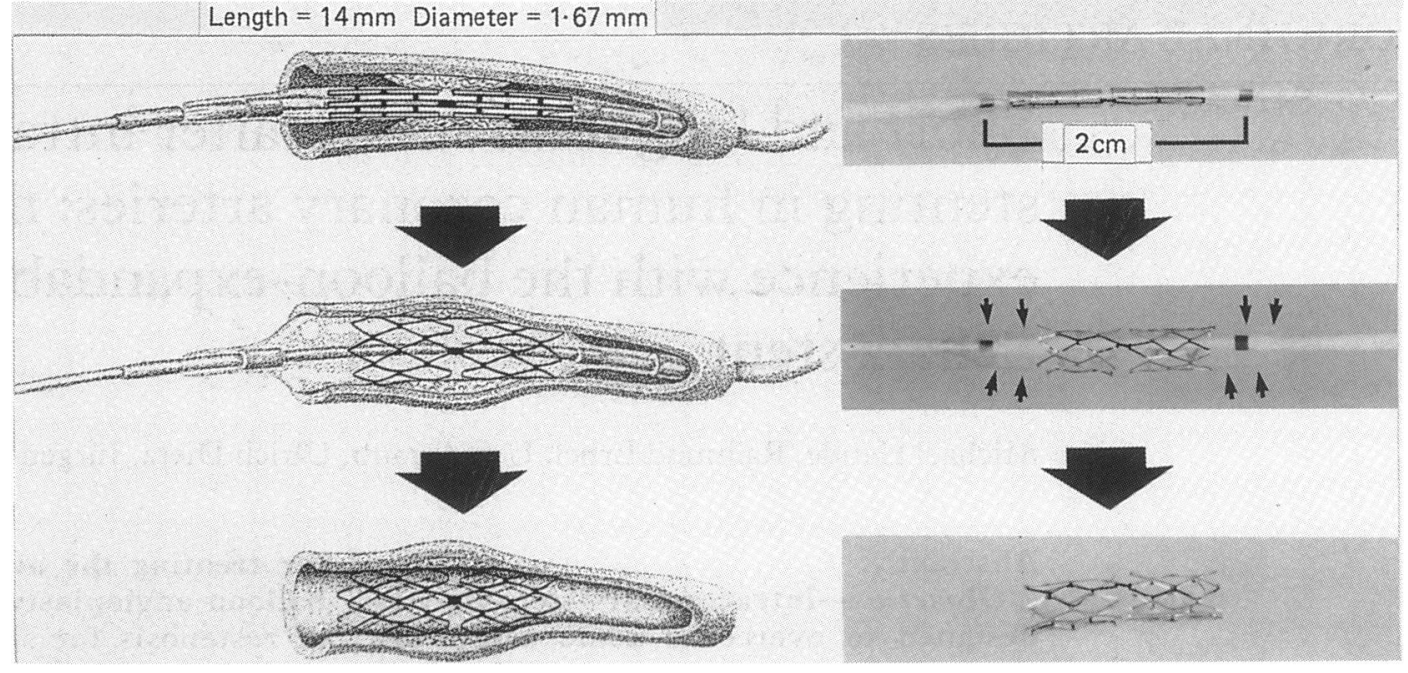

following indications: (a) restenosis after an initially successful coronary angioplasty procedure (31 patients); (b) inadequate angiographic result after balloon angioplasty with or without limitation of distal contrast medium run off (15 patients); (c) bail-out situations (16 patients with symptomatic dis- sections); (d) coronary bypass stenosis (one patient).

All patients gave their informed consent for the coronary balloon angioplasty procedure, for the stent implantation if at least one of the defined indications developed, and for a follow up coronary angiogram 4-6 months after im-

Table 1 Details of 50 patients in whom implantation of balloon-expendable Palmaz-Schatz stents was attempted

\begin{tabular}{|c|c|c|c|c|c|c|c|c|c|}
\hline \multirow[b]{2}{*}{ Case } & \multirow[b]{2}{*}{ Age } & \multirow[b]{2}{*}{ Sex } & \multirow[b]{2}{*}{ Risk factors } & \multirow{2}{*}{$\begin{array}{l}A P \\
C C S\end{array}$} & \multicolumn{2}{|l|}{ Previous } & \multirow{2}{*}{$\begin{array}{l}\text { Target } \\
\text { lesion }\end{array}$} & \multirow[b]{2}{*}{ Collaterals } & \multirow{2}{*}{$\begin{array}{l}\text { Indication } \\
\text { for stenting }\end{array}$} \\
\hline & & & & & PTCA & $M I$ & & & \\
\hline $\begin{array}{r}1 \\
2 \\
3 \\
4 \\
5 \\
6 \\
7 \\
8 \\
9 \\
10 \\
11 \\
12 \\
13 \\
14 \\
15 \\
16 \\
17 \\
18 \\
19 \\
20 \\
21 \\
22 \\
23 \\
24 \\
25 \\
26 \\
27 \\
28 \\
29 \\
30 \\
31 \\
32 \\
33 \\
34 \\
35 \\
36 \\
37 \\
38 \\
39 \\
40 \\
41 \\
42 \\
43 \\
45 \\
46 \\
47 \\
48 \\
49 \\
50\end{array}$ & $\begin{array}{l}47 \\
41 \\
60 \\
69 \\
66 \\
58 \\
65 \\
53 \\
67 \\
57 \\
55 \\
55 \\
47 \\
76 \\
58 \\
68 \\
68 \\
55 \\
64 \\
70 \\
64 \\
56 \\
61 \\
66 \\
50 \\
54 \\
56 \\
59 \\
61 \\
69 \\
61 \\
61 \\
60 \\
69 \\
64 \\
49 \\
64 \\
63 \\
64 \\
58 \\
49 \\
55 \\
52 \\
61 \\
60 \\
70 \\
51 \\
75 \\
69 \\
53\end{array}$ & $\begin{array}{l}M \\
M \\
M \\
M \\
M \\
M \\
M \\
M \\
M \\
M \\
M \\
M \\
M \\
M \\
M \\
M \\
M \\
M \\
M \\
M \\
M \\
M \\
M \\
M \\
M \\
M \\
M \\
M \\
M \\
F \\
M \\
M \\
M \\
M \\
M \\
M \\
M \\
M \\
M \\
M \\
M \\
M \\
M \\
M \\
M \\
F \\
M \\
M \\
M \\
M\end{array}$ & 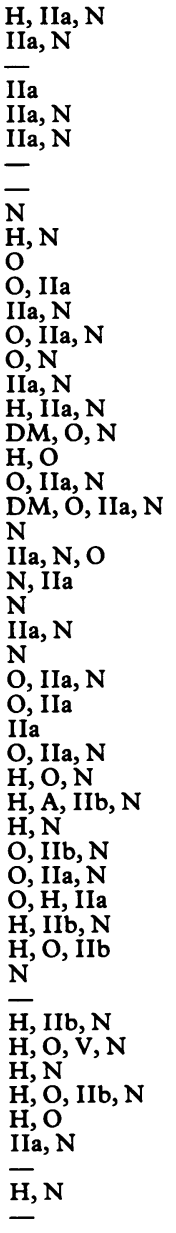 & $\begin{array}{l}\text { II } \\
\text { I } \\
\text { III } \\
\text { III } \\
\text { I } \\
\text { III } \\
\text { III } \\
\text { II } \\
\text { IV } \\
\text { III } \\
\text { III } \\
\text { II } \\
\text { II } \\
\text { III } \\
\text { III } \\
\text { I } \\
\text { III } \\
\text { II } \\
\text { II } \\
\text { III } \\
\text { III } \\
\text { II } \\
\text { II } \\
\text { III } \\
\text { III } \\
\text { III } \\
\text { III } \\
\text { II } \\
\text { I } \\
\text { II } \\
\text { II } \\
\text { II } \\
\text { II } \\
\text { III } \\
\text { I } \\
\text { IV } \\
\text { II } \\
\text { III } \\
\text { III } \\
\text { II } \\
\text { III } \\
\text { I } \\
\text { IV } \\
\text { II } \\
\text { III } \\
\text { III } \\
\text { II } \\
\text { III } \\
\text { III } \\
\text { III }\end{array}$ & 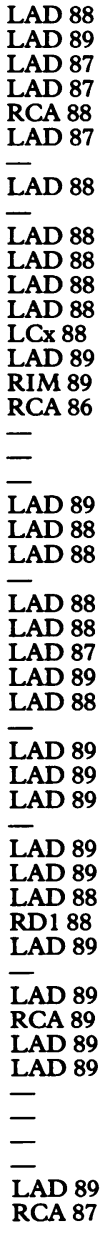 & $\begin{array}{l}88 \\
88 \\
\frac{88}{87} \\
\frac{87}{-} \\
\overline{88} \\
\frac{-}{-} \\
\overline{87} \\
\frac{88}{85} \\
\overline{-} \\
\frac{89}{-} \\
\frac{88}{88} \\
\frac{-}{88} \\
\frac{89}{88} \\
\frac{89}{88} \\
\frac{-}{-} \\
\frac{-}{87} \\
\overline{89} \\
\frac{89}{86} \\
84\end{array}$ & $\begin{array}{l}\text { LAD S } \\
\text { LAD Occ } \\
\text { LAD S } \\
\text { RCA Occ } \\
\text { RCA S } \\
\text { LAD S } \\
\text { RD1 Occ } \\
\text { LAD S } \\
\text { RCA S } \\
\text { LAD S } \\
\text { LAD S } \\
\text { LAD S } \\
\text { LAD S } \\
\text { LCx S } \\
\text { LAD S } \\
\text { RIM S } \\
\text { RCA S } \\
\text { LAD S } \\
\text { LAD S } \\
\text { RCA S } \\
\text { LAD Occ } \\
\text { LAD Occ } \\
\text { LAD S } \\
\text { RCA Occ } \\
\text { LAD S } \\
\text { LAD S } \\
\text { LAD S } \\
\text { LAD S } \\
\text { LAD Occ } \\
\text { LAD S } \\
\text { LAD S } \\
\text { LAD S } \\
\text { LAD S } \\
\text { LAD S } \\
\text { LAD S } \\
\text { LAD Occ } \\
\text { LAD S } \\
\text { RD1 S } \\
\text { LAD S } \\
\text { RCA S } \\
\text { LAD S } \\
\text { RCA S } \\
\text { LAD S } \\
\text { LAD S } \\
\text { RCA S } \\
\text { LAD S } \\
\text { SBG S } \\
\text { RCA S } \\
\text { RCA S } \\
\text { RCA S }\end{array}$ & $\begin{array}{l}\text { III } \\
\text { III } \\
\text { II } \\
\text { II } \\
\text { II } \\
\text { II } \\
\text { II } \\
\text { III } \\
\text { II } \\
\text { III } \\
\text { II } \\
\text { II } \\
\text { II } \\
\text { II } \\
\text { III } \\
\text { II } \\
\text { II } \\
\text { II } \\
\text { II } \\
\text { II } \\
\text { II } \\
\text { III } \\
\text { III } \\
\text { II } \\
\text { II } \\
\text { II } \\
\text { II } \\
\text { II } \\
\text { III } \\
\text { II } \\
\text { III } \\
\text { II } \\
\text { II } \\
\text { II } \\
\text { III } \\
\text { II } \\
\text { II } \\
\text { II } \\
\text { II } \\
\text { II } \\
\text { III } \\
\text { III } \\
\text { II } \\
\text { II } \\
\text { I } \\
\text { I } \\
\text { I } \\
\text { II }\end{array}$ & $\begin{array}{l}R \\
R \\
R, D, B \\
R, D, B \\
R, D, B \\
R \\
D, B \\
R \\
\text { Inad res } \\
R \\
R \\
R \\
R, D, B \\
\text { Inad res } \\
R, D, B \\
R, D, B \\
\text { Inad res } \\
D, B \\
D, B \\
D, B \\
R \\
R, \text { inad res } \\
R \\
\text { Inad res } \\
R, D, B \\
R \\
R \\
\text { Inad res } \\
\text { Inad res } \\
D, B \\
R, \text { inad res } \\
R \\
R \\
\text { Inad res } \\
R \\
R \\
R, D, B \\
R \\
\text { Inad res } \\
\text { Inad res } \\
R \\
R \\
R, D, B \\
R, \text { inad res } \\
\text { Inad res } \\
D, B \\
\text { SBG S } \\
D, B \\
\text { Inad res } \\
R, \text { inad res }\end{array}$ \\
\hline
\end{tabular}

$\mathrm{H}$, hypertension; $\mathrm{N}$, cigarette smoking; $\mathrm{O}$, obesity; IIa, IIb, and V, type of hyperlipoproteinaemia according to Fredrickson; AP, grade of angina pectoris according to the Canadian Cardiovascular Society (CCS); LAD, left anterior descending artery; RCA, right coronary artery; LCx, left circumflex artery; RD1, first diagona branch; RIM, intermediate branch; SBG, saphenous bypass graft; R, restenosis; D, dissection; B, bail-out; Inad res, inadequate angioplasty result; PTCA pranch; Reous transluminal coronary angioplasty; MI, myocardial infarction; Occ, occlusion; S, stenosis. 


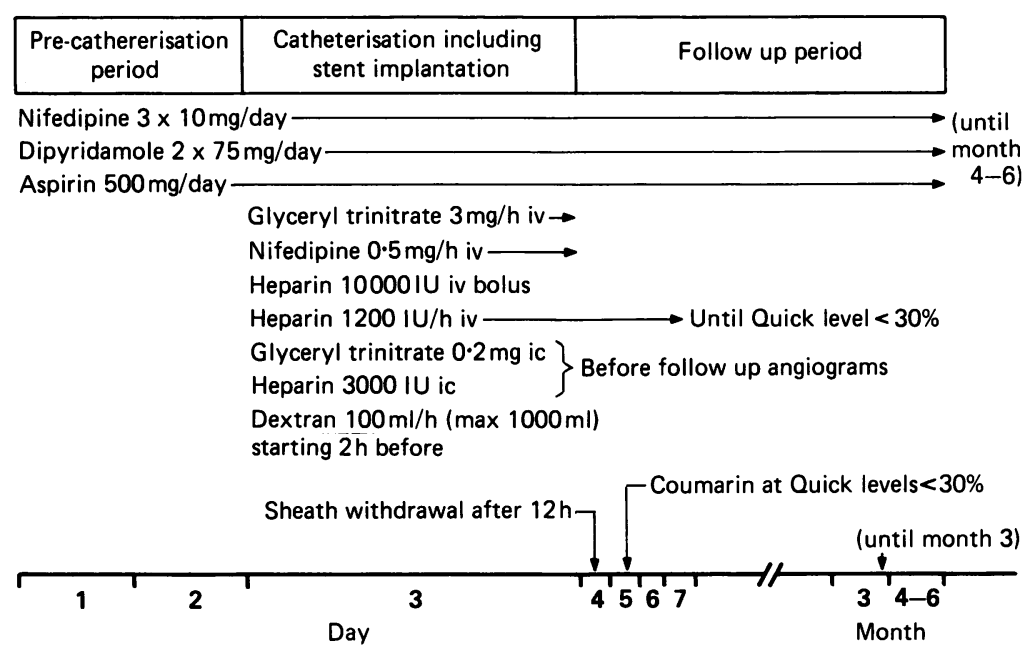

Figure 2 Medical treatment of patients undergoing intracoronary stenting. iv, intravenous; ic, intracoronary. performed in different oblique projections. The sheaths were withdrawn after $12 \mathrm{~h}$ and heparin infusion was continued for $48 \mathrm{~h}$. All patients were given continuous nifedipine, dipyridamole, and high dose aspirin until late follow up angiograms were performed after 4 6 months (fig 2). Starting with patient 8, coumarin was also given and heparin infusion was continued until Quick values $<30 \%$ were obtained. Because of the effect on subacute thrombosis after stent implantation reported by Schatz et al this anticoagulation treatment was continued for three months. ${ }^{29} 37$

\section{QUANTITATIVE CORONARY ANGIOGRAPHY}

Coronary luminal narrowing was estimated in two orthogonal views that give the best images of the target lesion. These views were also used to assess short and long term vessel patency. We calculated the absolute and relative minimal stenosis diameters according to the assumptions of Brown et $a l^{38}$ and we used the guiding catheter as a reference. Restenosis was defined as a reduction of $>50 \%$ in the lumen diameter or a loss of $>50 \%$ of the initial result.

\section{PROCEDURE}

Patients were treated with aspirin $(500 \mathrm{mg}$ ) (Colfarit), nifedipine $(3 \times 10 \mathrm{mg}$ ) (Adalat) and dipyridamole $(2 \times 75 \mathrm{mg})$ (Persantin forte) each day starting two days before the investigation (fig 2). In the catheterisation laboratory they were given $100 \mathrm{ml} / \mathrm{h}$ dextran before the procedure, an intravenous bolus injection of 10000 IU heparin, and continuous infusion of $1200 \mathrm{IU} / \mathrm{h}$ heparin, $0.5 \mathrm{mg} / \mathrm{h}$ nifedipine, and $3 \mathrm{mg} / \mathrm{h}$ glyceryl trinitrate (Perlinganit). After left ventricular angiography coronary angiograms of the left and right coronary arteries were performed in several projections to show the target lesion and the collateral supply. Angioplasty of the target lesion was then performed with $9 \mathrm{~F}$ guiding catheters (Medtronic, USA) and balloon catheters (ACX, ACS, and HydroCross; Edwards) with diameters ranging from 2.0 to $3.5 \mathrm{~mm}$. Intracoronary injections of $0.2 \mathrm{mg}$ glyceryl trinitrate and 3000 IU heparin were given before the follow up angiogram. If one of the defined indications was present we decided to implant a balloon-expandable Palmaz-Schatz stent. The Judkins guiding catheters were replaced by $9 F$ Amplatz guiding catheters via a $3 \mathrm{~m}$ guide wire where possible. Then the Palmaz-Schatz stent was mounted between the radiopaque markers of a $3.0 \mathrm{~mm}$ balloon catheter (USCI), which has a balloon length of $2.5 \mathrm{~cm}$ and can be inflated up to $14 \mathrm{~atm}$ (fig 1). The markers are needed to aid positioning of the stent because the mesh is not radiopaque. The long balloon covers the ends of the stent struts and prevents them damaging the vessel. The balloon with the mounted stent was then inserted into the target lesion and inflated to pressures up to 12 atm for 5-10s.

Another angioplasty was performed within the stent in 24 of 49 patients to achieve some overdilatation of the stented vessel segment and good fixation of the stent to the vessel wall (table 2). Finally, follow up angiograms were

\section{STATISTICAL ANALYSIS}

Minimal stenosis diameters are expressed as mean (1SD). We used analysis of variance, Student's $t$ test, the $\chi^{2}$ test, and Fisher's test, as appropriate, to test for significant changes. A probability of $p<0.05$ was regarded as significant.

\section{Results}

Figure 3 shows a successful stent implantation in a right coronary artery (patient 45). The indication for the implantation was an inadequate postangioplasty result after repeated balloon angioplasty with larger balloon catheters, longer inflation times, and increased inflation pressures. The severity of stenosis decreased considerably after stent implantation and the improvement persisted even after six months.

We successfully implanted $1-4$ stents per patient in 49 of 50 patients in whom intracoronary stenting was attempted. In one (patient 19) it was impossible to position the balloon catheter with the mounted stent into a predilatated but dissected lesion of the left anterior descending artery. Two other patients required additional angioplasties with larger balloons ( $3.5 \mathrm{~mm}$ diameter) before stent delivery could be successfully performed.

\section{COMPLICATIONS}

Acute thrombosis within the stent was seen immediately after implantation in one patient (patient 46), who had a dissected lesion of the anterior descending artery after angioplasty and a history of unstable angina. This patient was treated by an intracoronary bolus injection venous infusion of 1.5 million IU urokinase for 30 minutes. A non- $Q$ wave myocardial infarc-

\section{PRACTICABILITY} of 300000 IU urokinase and additional intra- 
Table 2 Individual angiographic results, balloon sizes, number of implanted stents, and complications in 50 patients

\begin{tabular}{|c|c|c|c|c|c|c|c|c|c|}
\hline \multirow[b]{2}{*}{ Case } & \multicolumn{4}{|c|}{ Minimal stenosis diameter } & \multicolumn{3}{|c|}{ Max balloon diameter } & \multirow[b]{2}{*}{$\begin{array}{l}\text { Implanted } \\
\text { stents }(n)\end{array}$} & \multirow[b]{2}{*}{ Complications } \\
\hline & $\begin{array}{l}\text { Pre } \\
\text { PTCA } \\
(\mathrm{mm})\end{array}$ & $\begin{array}{l}\text { Post } \\
\text { PTCA } \\
(\mathrm{mm})\end{array}$ & $\begin{array}{l}\text { With } \\
\text { stent } \\
(m m)\end{array}$ & $\begin{array}{l}4-6 \text { mnth } \\
(\mathrm{mm})\end{array}$ & $\begin{array}{l}P T C A \\
(m m)\end{array}$ & $\begin{array}{l}\text { Stent } \\
\text { implant } \\
(\mathrm{mm})\end{array}$ & $\begin{array}{l}\text { Stent } \\
\text { dilatation } \\
(\mathrm{mm})\end{array}$ & & \\
\hline 1 & 0.7 & $3 \cdot 2$ & 3.6 & $3 \cdot 1$ & 3 & 3.5 & - & 1 & - \\
\hline 2 & 0 & $2 \cdot 4$ & 2.8 & 0 & 3 & 3 & 二 & 2 & 二 \\
\hline 3 & 0.5 & 1.5 & 3.5 & $3 \cdot 2$ & 3 & 3 & - & 1 & $\overline{-}$ \\
\hline 4 & 0.2 & 2.5 & 3.4 & 0 & 3 & 3.5 & $\overline{-}$ & 4 & $\overline{-}$ \\
\hline 5 & 1.5 & 3.5 & 3.5 & 1 & 3 & 3.5 & - & 3 & $=$ \\
\hline 6 & 1 & 2.5 & 2.9 & - & 3.5 & 3 & - & 1 & Death \\
\hline 7 & 0.2 & 1.5 & 3 & 3 & 3 & 3 & 3 & 1 & - \\
\hline 8 & 1.5 & 2 & 3.6 & 1 & 2.5 & 3 & 3.5 & 1 & AVF \\
\hline 9 & 1 & 2 & 3.3 & $3 \cdot 3$ & 2.5 & 3 & 3.5 & 1 & - \\
\hline 10 & 0.7 & 2 & $3 \cdot 4$ & $2 \cdot 3$ & 2.5 & 3 & 3.5 & 2 & - \\
\hline 11 & 1.8 & 2 & 3.5 & 3.5 & 2.5 & 3 & 3.5 & 1 & GI bleed \\
\hline 12 & 1.3 & 2 & 3.4 & $2 \cdot 6$ & 2.5 & 3 & 3.5 & 2 & - \\
\hline 13 & 1.5 & 2 & $2 \cdot 8$ & $2 \cdot 6$ & 3 & 3 & - & 1 & Ging bleed \\
\hline 14 & 1 & $1 \cdot 5$ & 3.5 & $2 \cdot 4$ & 3.5 & 3.5 & - & 1 & Ging bleed \\
\hline 15 & 1 & 2 & 3.5 & 0 & $3 \cdot 5$ & $3 \cdot 5$ & 3.5 & 3 & SAT \\
\hline 16 & 15 & 1.5 & 3 & $2 \cdot 7$ & 3 & 3 & - & 1 & $\overline{c 10}$ \\
\hline 17 & 1.5 & 1.5 & 3 & 0 & $2 \cdot 5$ & 3 & - & 2 & SAT \\
\hline 18 & 0.5 & 2.5 & 3.5 & - & 3 & 3.5 & - & 1 & Dissec + CABG \\
\hline 19 & 0.8 & $2 \cdot 0$ & - & - & 3 & - & - & - & Impl impos \\
\hline 20 & 2.5 & 3 & 3.5 & 3.5 & $3 \cdot 5$ & 3.5 & - & 1 & \\
\hline 21 & $0 \cdot 2$ & 1.5 & 3 & 3 & 3 & 3 & - & 1 & SAT \\
\hline 22 & 0 & 1.5 & $2 \cdot 8$ & 2.5 & 3 & 3 & 3 & 1 & Ging bleed \\
\hline 23 & 0.9 & 2 & 3.5 & $3 \cdot 2$ & 3 & 3 & 3.5 & 1 & \\
\hline 24 & 0 & 2 & 3.4 & 3.3 & 3.5 & 3 & 3.5 & 1 & $-\ldots$ \\
\hline 25 & 1 & $2 \cdot 4$ & 3.5 & 2.5 & 3 & 3 & 3.5 & $i$ & GI bleed \\
\hline 26 & 0.9 & 2 & 3.5 & 3.5 & 3 & 3.5 & - & 1 & AVF, SAT \\
\hline 27 & 1.5 & 2.5 & 3.5 & 2.5 & 3 & 3 & - & 1 & - \\
\hline 28 & 1 & 1.5 & 3 & 0.8 & 3 & 3 & 3.5 & 1 & - \\
\hline 29 & $0 \cdot 2$ & 1.8 & 3 & $2 \cdot 8$ & 3 & 3 & - & 1 & - \\
\hline 30 & $1 \cdot 3$ & 2 & $3 \cdot 3$ & $1 \cdot 1$ & 3 & 3 & 3.5 & 1 & - \\
\hline 31 & 0.8 & 1 & 3.4 & 3.4 & 3.5 & 3.5 & - & 1 & - \\
\hline 32 & $\begin{array}{l}1.7 \\
\quad 1.7\end{array}$ & 2 & 3.5 & 3.4 & 3.5 & 3 & 3.5 & 1 & - \\
\hline 33 & $\begin{array}{l}1.8 \\
1.8\end{array}$ & $2 \cdot 3$ & 3 & 0.9 & 3 & 3 & - & 1 & - \\
\hline 34 & 1.5 & $2 \cdot 4$ & $3 \cdot 2$ & - & 3 & 3 & 3.5 & 1 & $\overline{-}$ \\
\hline 35 & 1.2 & 2.5 & 3 & - & 3 & 3 & - & 1 & - \\
\hline 36 & 0 & 2 & 3 & 3 & 3 & 3 & - & 1 & SAT \\
\hline 37 & 1.7 & $2 \cdot 5$ & $3 \cdot 4$ & 2.9 & 3 & 3 & 3.5 & $i$ & - \\
\hline 38 & 0.8 & 2 & 3 & 3 & 3 & 3 & 3.5 & 1 & - \\
\hline 39 & 0.9 & 1.8 & 3 & 3 & 3 & 3 & - & 1 & $\bar{z}$ \\
\hline 40 & 1.3 & 1.5 & 3 & 2.5 & 3.5 & 3 & 3.5 & 1 & - \\
\hline 41 & 0.4 & $2 \cdot 1$ & $3 \cdot 7$ & $3 \cdot 1$ & 3.5 & 3.5 & 4 & 1 & - \\
\hline 42 & 0.4 & $2 \cdot 3$ & 3 & 2.5 & 3 & 3 & - & 1 & - \\
\hline 43 & 0.8 & 1.8 & 3.5 & - & 3 & 3 & 3.5 & 1 & - \\
\hline 44 & 1 & 1.8 & 3.5 & $2 \cdot 8$ & 3 & 3 & 3.5 & 2 & Ging bleed \\
\hline 45 & 1.5 & 2 & 4 & 4 & 3 & $3 \cdot 5$ & 4 & 1 & \\
\hline 46 & 0.8 & 1.5 & $3 \cdot 1$ & $3 \cdot 1$ & 3 & 3 & - & 1 & Thrombus \\
\hline 47 & $1 \cdot 3$ & 2 & $2 \cdot 8$ & 0.5 & 3 & 3 & $\overline{25}$ & 1 & \\
\hline 48 & 1.5 & 1.6 & 3.5 & - & 3 & 3 & 3.5 & 1 & AVF \\
\hline 49 & 1.2 & 1.9 & 2.5 & - & 3 & $2 \cdot 5$ & - & 1 & SAT \\
\hline & 1.8 & 1.8 & 3.5 & $\overline{-a}$ & 3 & 3 & 3.5 & 1 & SAT, CABG \\
\hline Mean & 1.00 & 2.02 & $3 \cdot 26$ & 2.39 & 3.00 & $3 \cdot 10$ & 3.50 & - & - \\
\hline (SD) & 0.57 & 0.47 & 0.31 & $1 \cdot 15$ & 0.36 & 0.23 & 0.20 & - & - \\
\hline
\end{tabular}

PTCA, percutaneous transluminal coronary balloon angioplasty; AVF, arteriovenous fistula; GI bleed, gastrointestinal bleeding; Ging bleed, gingival bleeding; SAT, subacute stent thrombosis; CABG, coronary artery bypass grafting; impl impos, implantation impossible; dissec, dissection.

tion with a maximum rise in creatinekinase to $400 \mathrm{IU} / 1$ developed. A follow up angiogram after $24 \mathrm{~h}$ showed vessel patency without any persisting thrombus formation.

One patient (patient 18) was sent for elective bypass surgery $24 \mathrm{~h}$ after stent implantation because of persisting angina but without changes on electrocardiogram or in creatine kinase activity. In this patient, who presented with a stenosis of the left anterior descending coronary artery near to the origin of the first diagonal branch, the guide wire could be placed only in the diagonal branch and not in the distal left anterior descending coronary artery. After balloon angioplasty there was a long dissection at the site of dilatation that altered blood flow in the distal part of the left anterior descending coronary artery even after successful stent implantation.

Symptomatic thrombotic complications including vessel closure occurred in seven patients 5-9 days after stent implantation. These were regarded as subacute complica- tions in view of the interval since implantation. Table 3 shows individual data on stent implantation, the time of subacute vessel closure, the medication, and the coagulation indices for these seven patients. Suboptimal anticoagulation or antiaggregation at the time of vessel closure was found in two of seven patients, which means that either coumarin, aspirin, and/or dipyridamole were not given, or given in inadequate doses. Reopening of the stented vessel was achieved by thrombolysis or mechanical recanalisation and balloon angioplasty in five of seven patients. The two patients in which these measures failed were sent for bypass surgery-one immediately and the other four months later because of persisting angina and an abnormal stress test despite good collateral supply of the target vessel. Three patients developed $Q$ wave myocardial infarctions and two non- $Q$ wave myocardial infarctions. Late follow up coronary angiograms after stent implantation, performed in four of five thrombolytically or mechanically recanalised 

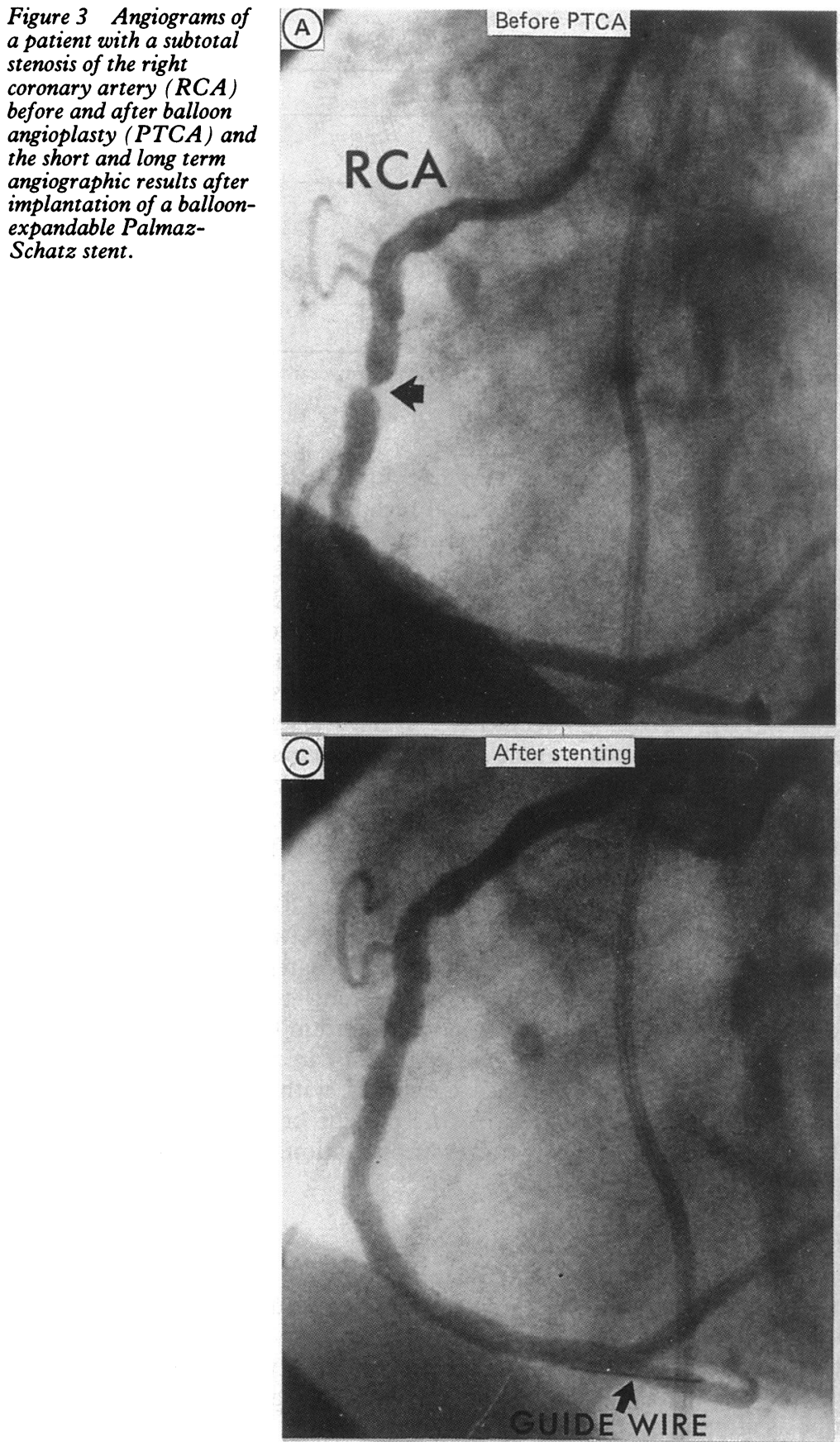

patients, showed long term vessel patency in three. The other presented with late reocclusion and was successfully recanalised by angioplasty.

One patient (case 6) died out of hospital 10 days after implantation of an unknown cause. Necropsy was not performed.

Major bleeding complications requiring blood transfusions occurred in five patients $(10 \%)$ (gastrointestinal bleeding in two patients during the follow up period and haematoma in the groin with arteriovenous fistulae in three patients after sheath withdrawal). Minor bleeding complications such as gingival bleeding occurred in four patients $(8 \%)$.

\section{QUANTITATIVE CORONARY ANGIOGRAPHY}

Visual inspection of the coronary angiograms after stent implantation showed smooth vessel wall segments without any wall irregularities in
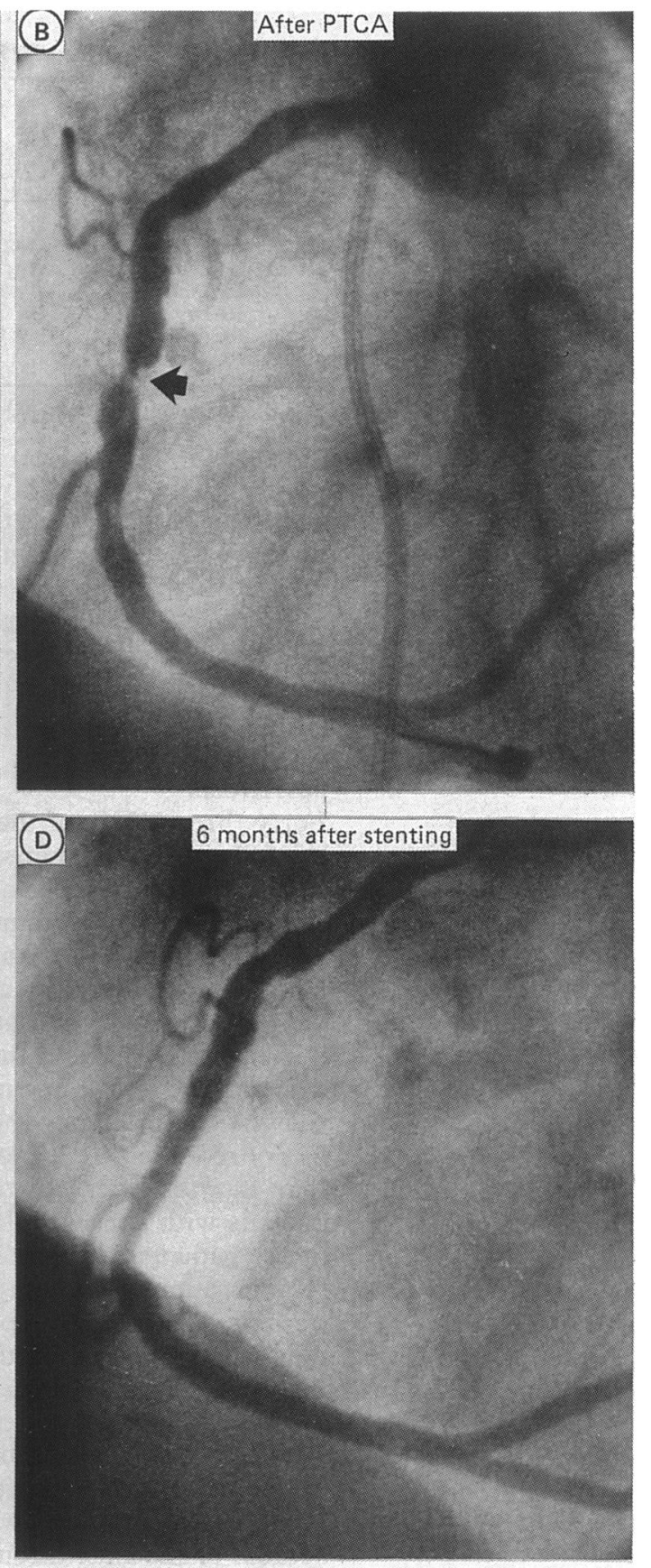

most cases, in contrast to the usual appearance after balloon angioplasty. Especially in patients with large and symptomatic dissections after balloon angioplasty the intimal and medial flaps were successfully wrapped against the vessel wall in 15 of 16 leaving no angiographic signs of residual stenosis.

Table 2 shows the individual results of the quantitative analysis of the minimal luminal narrowing before and after balloon angioplasty, after intracoronary stenting, and four to six months later together with data on maximum balloon sizes for balloon angioplasty and stent implantation. The mean (1 SD) minimal luminal diameter after balloon angioplasty was $2.02(0.47) \mathrm{mm}$ compared with $1.00(0.57) \mathrm{mm}$ before angioplasty ( $p<0.001)$. After stent implantation there was a further increase in luminal diameter to $3.26(0.31) \mathrm{mm}(\mathrm{p}<$ 0.001 ). In contrast, the mean maximum balloon size for angioplasty was $3.00(0.36) \mathrm{mm}$ 
Table 3 Individual procedure-related data, medication, and anticoagulation variables of seven patients with subacute thrombosis after implantation of balloon-expandable Palmaz-Schatz stents

\begin{tabular}{|c|c|c|c|c|c|c|c|c|}
\hline \multirow[b]{2}{*}{$\begin{array}{l}\text { No } \\
\text { case }\end{array}$} & \multirow[b]{2}{*}{$\begin{array}{l}\text { Target } \\
\text { lesion }\end{array}$} & \multirow[b]{2}{*}{ Collaterals } & \multirow[b]{2}{*}{ Stents } & \multirow{2}{*}{$\begin{array}{l}\text { Time of } \\
S A T \\
\text { (days) }\end{array}$} & \multicolumn{4}{|c|}{ Medication } \\
\hline & & & & & Coumarin & $\begin{array}{l}\text { Heparin } \\
(I U / h)\end{array}$ & $\begin{array}{l}\text { Aspirin } \\
\text { (mg) }\end{array}$ & Dipyridamole \\
\hline $\begin{array}{l}15 \\
17 \\
21 \\
26 \\
36 \\
49 \\
50\end{array}$ & $\begin{array}{l}\text { LAD sten } \\
\text { RCA sten } \\
\text { LAD occl } \\
\text { LAD sten } \\
\text { LAD sten } \\
\text { RCA sten } \\
\text { RCA sten }\end{array}$ & $\begin{array}{l}\text { III } \\
\text { II } \\
\text { II } \\
\text { II } \\
\text { II } \\
\text { I } \\
\text { II }\end{array}$ & $\begin{array}{l}3 \\
2 \\
1 \\
1 \\
1 \\
1 \\
1\end{array}$ & $\begin{array}{l}9 \\
7 \\
6 \\
8 \\
9 \\
5 \\
5\end{array}$ & $\begin{array}{l}+ \\
+ \\
+ \\
+ \\
+ \\
+ \\
+\end{array}$ & $\begin{array}{l}z \\
= \\
\overline{-} \\
1000 \\
1200\end{array}$ & $\begin{array}{l}500 \\
500 \\
100 \\
500 \\
500 \\
500\end{array}$ & $\begin{array}{l}+ \\
+ \\
+ \\
+ \\
+ \\
+ \\
+\end{array}$ \\
\hline
\end{tabular}

Sten, stenosis; occl: occlusion, nQ MI: non- $Q$ wave myocardial infarction; $Q \mathrm{MI}$ : $\mathrm{Q}$ wave myocardial infarction, $\mathrm{CK}$, creatine kinase $\mathrm{MB}$

and for stent implantation $3.10(0.23) \mathrm{mm}$, giving balloon:vessel ratios of 0.9 and 0.95 , respectively.

There was a $33 \%$ decrease in the maximum achievable diameter measured after balloon angioplasty but almost no loss after stenting (fig 4).

\section{RESTENOSIS}

Forty three $(89 \%)$ of the 47 suitable patients had follow up angiograms (fig 5). Five symptom free patients refused scheduled late coronary angiography. Angiograms were performed in $36(84 \%)$ of the 43 suitable patients four to six months after stenting and in seven (16\%) before this scheduled date because of thrombotic complications. In the group of 36 patients who had the follow up angiography, $28(78 \%)$ showed vessel patency and eight $(22 \%)$ restenosis or reocclusion. Angiograms were obtained four months after stenting in five of seven patients with subacute thrombosis. In four of these patients thrombolysis or mechanical recanalisation was successful and in another it was not. Thus $41(84 \%)$ patients had long term follow up angiograms after four to six months that showed open vessels without restenosis in 31 patients $(76 \%)$, restenosis in six patients $(15 \%)$, and reocclusion in four patients $(9 \%)$, of whom one had successful and another unsuccessful recanalisation, which was attempted because of subacute thrombosis after stenting.

Only three of eight patients with multiple stents had patent vessels four to six months after stenting. One had late restenosis and four had late reocclusion. In contrast $28(85 \%)$ of the 33 patients with single stents had patent vessels four to six months after stenting; three

Figure 4 Minimal luminal diameters (mean (1SD)) before and after balloon angioplasty and after implantation of balloon-expandable Palmaz-Schatz stents compared with the maximum balloon diameters used. of them had had successful thrombolysis or mechanical recanalisation because of subacute stent thrombosis. Late restenosis was found in five $(15 \%)$ of 33 patients with single stent implantation ( $p<0.02$ compared with multiple stent implantation). No late vessel occlusion occurred in these patients.

Mechanical recanalisation of chronically occluded coronary arteries was attempted in eight of the 50 patients. In six this achieved long term vessel patency; in two there were late reocclusions.

Coumarin had been given to 35 of the 41 patients who had long term follow up coronary angiography-seven $(20 \%)$ with late restenosis or reocclusion and $28(80 \%)$ patients in whom the vessel remained patent. In those not treated with coumarin long term restenosis or reocclusion was found in three patients and long term vessel patency in two (no significant difference compared with the coumarin treated group). One patient in this subgroup died 10 days after implantation.

\section{Discussion}

Restenosis after an initial successful coronary angioplasty procedure, inadequate postangioplasty results, coronary venous bypass stenosis, and bail-out situations are commonly accepted indications for stent implantation. ${ }^{1921-2427-32}$ The rate of successful implantation was $98 \%$, which is comparable to the results of other groups and to the rate of success for pure balloon angioplasty procedures. ${ }^{24293137}$ Although the balloon with the mounted stent becomes somewhat stiffer, we were able to pass most lesions. The importance of sufficient predilatation was demonstrated in two patients who required another angioplasty before stent delivery was successful. Nevertheless, in tortuous lesions it can be difficult if not impossible to pass the lesion with this device, as occurred in one patient.

Acute complications were less common after stent implantation than after coronary balloon angioplasty. Severe complications such as acute thrombosis or dissections resulting in acute vessel closure were reported in $1.1-8 \%$ of patients after coronary balloon angioplasty..$^{571-13}$ Only one of our patients had acute thrombosis immediately after stent implantation. This patient had unstable angina. The reported rates of thrombosis and acute vessel 
Table 3 continued

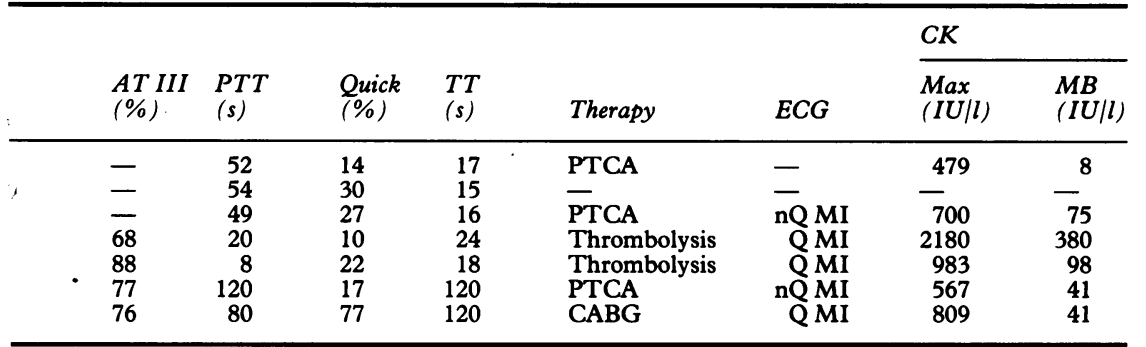

fraction. See footnotes to tables 1 and 2 for other abbreviations.

closure after angioplasty are higher in patients with unstable angina. ${ }^{89}$

Sixteen of 50 patients needed a bail-out procedure after balloon angioplasty, because they had symptomatic coronary dissections with angiographically documented flaps. The flaps were wrapped against the vessel wall in most cases and there was a considerable reduction in symptoms and ischaemic electrocardiographic changes. Previous investigators have discussed the relation between the extent of dissections and the rate of acute complications including vessel closure and the request for urgent bypass surgery. ${ }^{1518}$ Vessel wall irregularities such as intimal and medial flaps alter blood flow and promote thrombus formation. There were no acute vessel closures or requests for urgent bypass surgery among our patients, even those with symptomatic dissec-

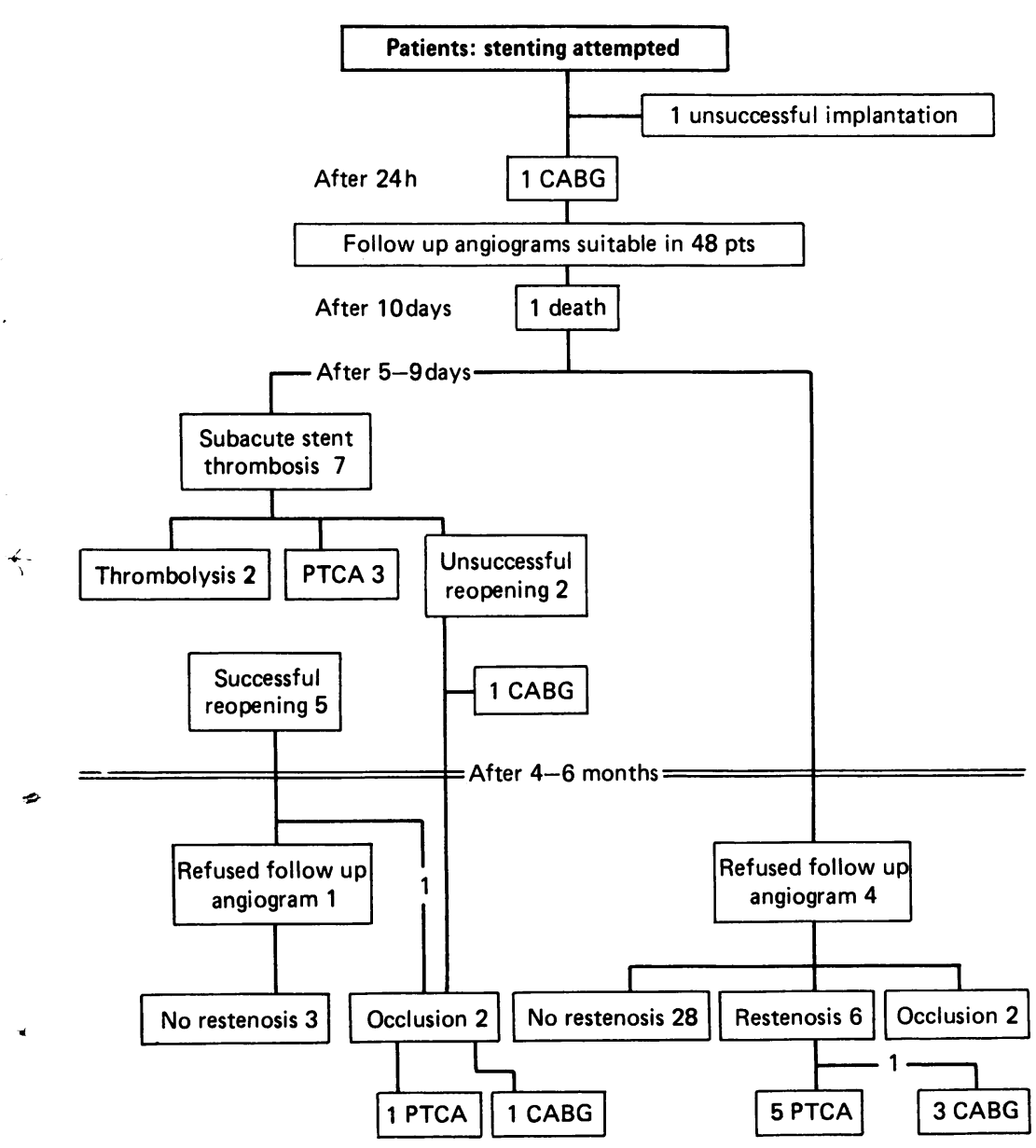

Figure 5 Flow chart of the results of restenosis in 50 patients, in whom intracoronary implantation of balloon-expandable Palmaz-Schatz stents was attempted. tions. In one patient who had a long dissection after angioplasty of a lesion of the left anterior descending artery a single stent was implanted but a residual distal flap persisted and altered blood flow in the distal part of the vessel even after stenting. This patient was sent for elective bypass surgery the next day. This case emphasises the application of "over the wire techniques" for stent implantation with proper positioning of the wire in the distal part of the target vessel and not in side branches, especially those that originate next to the target lesion. The long wire technique allows easy exchange of balloon catheters for angioplasty and stent delivery even in the presence of dissections. It also provides a stable back up when the stent device is advanced.

Subacute stent thrombosis five to nine days after implantation must be regarded as a new device-related problem. It was reported in $18 \%$ of 39 patients not treated with warfarin and in $0.6 \%$ of 174 patients treated with warfarin who had a Palmaz-Schatz stent implanted. ${ }^{29}{ }^{37}$ Serruys et al reported 25 (21 within the first 14 days) subacute vessel closures in 105 patients receiving a self-expandable Medinvent stent. ${ }^{28} 39$ This confirmed previous reports. ${ }^{24}$ Similar results have been reported for Gianturco and Wiktor stents. The rate of subacute vessel closures was $10 \%$. Schatz, ${ }^{29} 37$ recommended that all patients with stent implantation should be treated with long term medication including high dose aspirin (500 mg/day). dipyridamole, and additional coumarin to prevent subacute thrombotic complications. Nevertheless, seven $(14 \%)$ of our patients had a subacute stent thrombosis. Retrospective analysis showed that anticoagulation or antiplatelet aggregation treatment had been inadequate in two of seven patients. On the other hand, five patients who were given optimal medical treatment also had subacute stent thrombosis. In five patients subacute vessel closure occurred soon after heparin was stopped. Although routine serum coagulation indices (prothrombin ratio, activated partial thromboplastin time, Quick levels) were optimal, stopping heparin after several days treatment may have promoted increased rebound coagulation. More detailed analysis of the patients' individual coagulation state showed that the prothrombin fragments $F 1$ and $F 2$ are better indices for predicting subacute stent thrombosis. ${ }^{4041}$ Also, coagulation factor II is a better index of coumarin induced anticoagulation than the Quick value especially before intravenous heparin is stopped.

Bleeding complications occurred in nine $(18 \%)$ patients; five needed blood transfusions. This was a somewhat higher rate than that associated with coronary angioplasty alone. ${ }^{213}$ The most likely explanation is the extended anticoagulation and antiplatelet aggregation treatment.

One patient died of an unknown cause out of hospital 10 days after implantation. Necropsy was not performed. This patient did not receive coumarin. There was no evidence of stent related death or myocardial infarction asso- 
Table 4 Different definitions of restenosis applied to the late angiographic results after implantation of balloon-expandable Palmaz-Schatz stents

\begin{tabular}{|c|c|c|c|c|c|c|}
\hline \multirow[b]{3}{*}{ Definition of restenosis } & \multicolumn{6}{|c|}{ Rate of restenosis (\%) } \\
\hline & \multicolumn{2}{|c|}{ Stent implantation } & \multicolumn{2}{|c|}{ Single stent implantation } & \multicolumn{2}{|c|}{ Multiple stent implantation } \\
\hline & $\begin{array}{l}\text { With } S A T \\
(n=41)\end{array}$ & $\begin{array}{l}\text { Without } S A T \\
(n=36)\end{array}$ & $\begin{array}{l}\text { With } S A T \\
(n=33)\end{array}$ & $\begin{array}{l}\text { Without } S A T \\
(n=30)\end{array}$ & $\begin{array}{l}\text { With } S A T \\
(n=8)\end{array}$ & $\begin{array}{l}\text { Without } S A T \\
(n=6)\end{array}$ \\
\hline \multirow{5}{*}{$\begin{array}{l}>50 \% \text { diameter reduction and }>50 \% \text { loss } \\
\text { of the post-stent result } \\
>30 \% \text { decrease in diameter at follow up } \\
\text { compared with the post-stent result } \\
>70 \% \text { diameter reduction and }>50 \% \text { loss } \\
\text { of the post-stent result } \\
\text { Decrease in diameter at follow up to within } \\
10 \% \text { of the predilatation diameter } \\
>50 \% \text { loss of the post-stent result } \\
>0.72 \text { mm reduction in diameter at follow } \\
\text { up compared with the post-stent result }\end{array}$} & 24 & 22 & 15 & 17 & 63 & 50 \\
\hline & 29 & 28 & 21 & 17 & 63 & 50 \\
\hline & 24 & 22 & 15 & 17 & 63 & 50 \\
\hline & $\begin{array}{l}24 \\
27\end{array}$ & $\begin{array}{l}22 \\
22\end{array}$ & $\begin{array}{l}15 \\
18\end{array}$ & $\begin{array}{l}17 \\
17\end{array}$ & $\begin{array}{l}63 \\
63\end{array}$ & $\begin{array}{l}50 \\
50\end{array}$ \\
\hline & 37 & 36 & 24 & 27 & 88 & 83 \\
\hline
\end{tabular}

SAT, subacute stent thrombosis.

ciated with vessel closure although the timing does not differ from that of subacute stent thrombosis. One stent related death has been reported from the central registry for the Palmaz-Schatz stent. ${ }^{29} 37$

There was a $33 \%$ loss in the maximum achievable diameter after balloon angioplasty compared with almost no loss after stenting, though the maximum balloon:vessel ratios were similar. This is a commonly known limitation of coronary balloon angioplasty and is in part brought about by the elastic recoil forces of the coronary arteries. ${ }^{42-44}$ Balloon-expandable stenting improved the angiographic results of the lesion dimensions by inhibiting these elastic recoil forces. The residual area stenosis after implantation of self-expandable Medinvent stents was reported to be about $36 \%{ }^{43}$ and the residual diameter stenosis $22 \%$ immediately afterwards and $17 \%$ after 24 hours, ${ }^{44}$ which is considerably higher than our results for mean residual diameter stenosis after balloonexpandable stenting, which was less than $5 \%$.

Despite the small number of patients studied we analysed our data to obtain information about the rate of late restenosis after coronary stent implantation. The rate of restenosis and reocclusion was calculated to be $24 \%$ compared with about $30 \%$ after coronary balloon angioplasty. ${ }^{17}$ Because the data for restenosis depend on the definition used, we also calculated the rate of restenosis for other frequently used definitions (table 4). Patients with single stent implantation showed better long term vessel patency than patients with multiple stents; this finding accords with Schatz's data. ${ }^{37}$

We conclude that wherever possible multiple stent implantation should be avoided for a single coronary lesion. The possible reasons for the poor long term outcome of multiple coronary stent implantation are an increased thrombophilia and induction of intimal proliferation, especially when there is an overlap of two adjacent stents. ${ }^{25} 29$ Additional treatment with coumarin did not tend to influence the rate of late restenosis-in contrast to the results reported earlier. ${ }^{37}$ However, only seven patients were not treated with coumarin compared with 41 patients who were. This may explain the outcome. Nevertheless, long term coumarin treatment (for at least three months) must be reconsidered because we found no evidence that it inhibited subacute stent thrombosis or late restenosis while bleeding complications were more common.

Statistical analysis did not identify any other risk factors for late restenosis in these patients, such as balloon size, inflation pressure, duration of inflation, absence or presence of dissections, or the resulting vessel diameters.

Intracoronary implantation of balloonexpandable Palmaz-Schatz stents is a new, highly feasible interventional technique. Management of acute complications after coronary balloon angioplasty was especially successful. Currently the long term outcome seems to be open, though we did find a significantly lower restenosis rate when single stents were used. In our opinion, subacute stent thrombosis must be regarded as a new, serious complication and a limitation of this promising method, which our results suggest cannot be counteracted by extended anticoagulation and antiplatelet aggregation treatment but by improved coagulation monitoring.

1 Grüntzig AR, King SB, Schlumpf $M$, Siegenthaler $W$ Long-term follow-up after percutaneous transluminal cong-ary angioplasty. The early Zurich experience. N Engl J Med 1987;616:1127-32.

2 Grüntzig AR. Percutaneous transluminal coronary angioplasty: 6 years experience. Am Heart $J$ 1984;107:818-23.

Kaltenbach M, Kober G, Scherer D. Mechanische Dilatation von Koronararterienstenosen (Transluminale Angiotion von Koronararterienstenosen
plastie). $Z$ Kardiol 1980;69:1-10.

4 Meyer J, Erbel R, Pop T, Rupprecht HJ. Derzeitiger Stand der intrakoronaren Ballondilatation. Internist (Berl) der intrakoronaren

5 Rupprecht HJ, Ërbel R, Brennecke R, et al. Aktuelle Komplikationsrate der perkutanen transluminalen Koronar-angioplastie bei stabiler und unstabiler Angina. Disch Med Wochenschr 1988;113:409-13.

6 Ellis SG, Roubin GS, King SB, et al. In-hospital mortality after acute closure after coronary angioplasty: analysis of risk factors from 8207 procedures. J Am Coll Cardio 1988;11:211-6.

7 Akins CW, Block PC. Surgical interventions for failed percutaneous transluminal coronary angioplasty. Am Cardiol 1984;53:108C-11C.

8 Erbel R, Schmitz HJ, Meyer J, et al. Percutaneous transluminal coronary angioplasty in patients with unstable luminal coronary angioplasty in patien

9 Meyer J, Schmitz H, Erbel R, et al. Treatment of unstable angina pectoris with percutaneous transluminal coronary angioplasty. Cathet Cardiovasc Diagn 1981;7:361-71.

10 Vandormael MG, Deligonul U, Kern MJ, et al. Multilesion coronary angioplasty: clinical and angiographic follow-up. coronary angioplasty: clinical and an

11 Cowley MJ, Dorros G, Kelsey SF, et al. Emergency coronary bypass surgery after coronary angioplasty: the National Heart, Lung, and Blood Institute's percutaneous transluminal coronary angioplasty registry experience. Am J Cardiol 1984;53:22C-6C

12 Shiu MF, Silverton NP, Oakley D, Cumberland D. Acute coronary occlusion during percutaneous transluminal coronary angioplasty. Br Heart J 1985;54:129-33.

13 Steffenino G, Meier B, Finci L, et al. Acute complications of 
elective coronary angioplasty: a review of 500 consecutive procedures. Br Heart J 1988;59:151-8.

14 Bredlau C, Roubin GS, Leimgruber PP, et al. In-hospital morbidity and mortality in patients undergoing elective coronary angioplasty. Circulation 1985;5:1044-52.

15 Leimgruber PP, Roubin GS, Anderson HV, et al. Influence of intimal dissection on restenosis after successful coronary angioplasty. Circulation 1985;72:530-5.

16 Galan KM, Deligonul U, Kern MJ, et al. Increased frequency of restenosis in patients continuing to smoke frequency of restenosis in patients continuing to smoke
cigarettes after percutaneous transluminal coronary cigarettes after percutaneous translum

17 Kaltenbach M, Kober G, Schmidt-Moritz A, Scherer D. Rezidivhäufigkeit nach erfolgreicher transluminaler Koronarangioplastie. Dtsch Med Wochenschr 1983;108: 1387-90.

18 Matthews BJ, Ewels CJ, Kent KM. Coronary dissection: a predictor of restenosis? Am Heart J 1988;115:547-54.

19 Sigwart U, Urban P, Golf S, et al. Emergency stenting for acute occlusion after coronary balloon angioplasty. Circulation 1988;78:1121-7.

20 Roubin GS, Douglas JS, Lembo NJ, et al. Intracoronary stenting for acute vessel closure following percutaneous transluminal coronary angioplasty (PTCA) [abstract]. Circulation 1988;78(suppl II):II-406.

21 De Feyter PJ, DeScheerder I, van den Brand M, Laarman GJ, Suryapranata H, Serruys PW. Emergency stenting for GJ, Suryapranata $H$, Serruys $P W$. Emergency stenting for refractory acute coronary artery occlusion during

22 Haude M, Erbel R, Straub U, Dietz U, Schatz R, Meyer J. Results on intracoronary stents for management of coronary dissection after balloon angioplasty. Am J Cardiol 1991;67:691-6.

23 Puel J, Rousseau H, Joffre F, et al. Intravascular stents to prevent restenosis after transluminal coronary angioplasty [abstract]. Circulation 1987;76(suppl IV):27.

24 Puel J, Juilliere Y, Bertrand ME, et al. Early and late assessment of stenosis geometry after coronary arterial stenting. Am J Cardiol 1988;61:546-53.

25 Schatz RA. A view of vascular stents. Circulation 1989;79: 445-57.

26 Roubin GS, King SB III, Douglas JS Jr, et al. Intracoronary stenting during percutaneous transluminal coronary angioplasty. Circulation 1990;81(suppl IV):IV92-100.

27 Erbel R, Schatz R, Diert U, et al. Percutaneous translumina coronary stent implantation. Z Kardiol 1989;78:71-7.

28 Serruys PW, Strauss BH, Beatt KJ, et al. Angiographic follow-up after placement of a self-expanding coronaryartery stent. N Engl J Med 1991;324:13-7.

29 Schatz RA, Baim DS, Leon M, et al. Clinical experience with the Palmaz-Schatz ${ }^{\mathrm{IM}}$ coronary stent: initial results of a multicenter study. Circulation 19??;83:148-61.

30 Sigwart U, Puel J, Mirkovitch V, et al. Intravascular stents to prevent occlusion and restenosis after transluminal angioplasty. $N$ Engl J Med 1987;316:701-6.

31 Sigwart U, Imbert C, Essinger A, et al. One year percutaneous coronary stenting [abstract]. Circulation 1987; 76(suppl IV):26.

32 Urban $\mathrm{P}$, Sigwart U, Golf $S$, et al. Intravascular stenting for stenosis of aortocoronary venous bypass grafts. J Am Col stenosis of aortocoronary

33 Palmaz JC, Sibbitt RR, Tio FO, et al. Expandable intraluminal vascular graft: a feasibility study. Surgery 1986 99:199-205.

34 Palmaz JC, Kopp DT, Hayashi $\mathrm{H}$, et al. Normal and stenotic renal arteries: experimental balloon-expandable intraluminal stenting. Radiology 1987;164:705-8.

35 Palmaz JC, Windeler SA, Garcia F, et al. Atherosclerotic rabbit aortas: expandable intraluminal grafting. Radiology 1986;160:723-6.

36 Schatz RA, Palmaz JC, Tio FO, et al. Balloon-expandable intracoronary stents in the adult dog. Circulation 1987; 76:450-7.

37 Schatz RA, Leon MB, Baim DS, et al. Balloon expandable intracoronary stents: initial results of a Multicenter Study intracoronary stents: initial results of a Multicent

38 Brown BG, Bolson E, Frimer M, Dodge HT. Quantitative coronary arteriography. Circulation 1977;55:329-37.

39 Serruys PW, Beatt KJ, van der Giessen WJ. Stenting of coronary arteries. Are we the sorcerer's apprentice? Eur Heart $J 1989 ; 10: 774-82$

40 Swars H, Hafner G, Erbel R, et al. Prothrombin fragmen and thrombotic occlusion of coronary stents. Lancet 1991 337:59.

41 Swars H, Hafner G, Erbel R, et al. Prothrombinfragment $\mathrm{F} 1+2$ predicts acute occlusion after intracoronary stenting [abstract]. J Am Coll Cardiol 1991;17:302A.

42 Rensing BJ, Serruys PW, Beatt KJ, et al. Densitometrically observed differences in elastic recoil of the three main coronary arteries after percutaneous transluminal coronary angioplasty [abstract]. J Am Coll Cardiol 1990; ary ang

43 Serruys $\mathrm{PW}$, Juilliere $\mathrm{Y}$, Bertrand ME, et al. Additional improvement of stenosis geometry in human coronary arteries by stenting after balloon dilatation. $\mathrm{Am} J$ Cardiol 1988;61:710-6G

44 Beatt KJ, Bertrand M, Puel J, et al. Additional improvement in vessel lumen in the first 24 hours after stent implantation due to radial dilating force [abstract]. $\mathrm{J} \mathrm{Am} \mathrm{Coll} \mathrm{Cardiol}$ 1989;13:224A. 